\title{
実践産出のメカニズムとハビトゥスの変容可能性とを巡って \\ On the Mechanism of Production of Practice and the Possibility of Transformation of Habitus
}

\section{平林 豊樹 HIRABAYASHI Toyoki}

In P. Bourdieu's theory of practice, habitus is a principal concept. Also, habitus importantly combines with other concepts of Bourdieu, for example, "field" , "capital" , etc.

I examine the function of habitus and the possibility of its transformation, through probing into case-studies of Bourdieu and a scholar of the Bourdieu-school ( $P$. Champagne). By this examination, it becomes clear that the theory of practice can analyze historical social changes. Aditionally, I intend to show that habitus, which tends to reproduce objective structures of the social world, still provides for the possibility of the transformation.

\section{1.問題の所在}

P.ブルデューの社会学に於いて、実践 (la pratique) は、「当事者のハビトゥス」と「社 会的世界がその当事者に客瞄的に与えるチャンスの一定の状热」との関保によって定まる、 とされている[Bourdieu, $1980: 107 \sim 109=1989: 103 \sim 104]$ 。又、行為者 (agent) たる「当事者」は、「場」に所属し、「資本」を有しているから、「社会的世界がその当

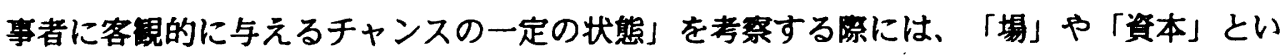
った椹念が念頭に置かれなければならない。つまり、例えば「ハビトゥス」概念を考察し ようとするならば、その概念そのものについて哲学的な思索を巡らすことと並んで、それ を行為者の属する「場」や「資本」との拘わりに於いて捉えることも必要だろう。

上記の内容を「実践産出のメカニズム」と呼ぶとすれば、それは、その時々の状況に合 わせてのハビトゥスの出現である「戦略」という概念と相俟って、時代や埸に拘束された 行為者の実践を説明し得るものだ。だが、再生産の分析、及び笨造的分析を為し得ると同 時に、行為者の実践をも説明し得るブルデューの理論に対して、「階級（階首）関係の再 生産ばかりを強調している」とか、「非歴史的分析ばかりである」といった、一面的な見 方に基づく非離が為されているのも事実である。

例えば、ブルテューは歴史や歴史的変容を説明する気が無く、その様な説明を主眼とし たことも無い、とR.ハーカーらは言う [Harker,1990＝1993 :296〜297.] (1) 。又、 D.ガートマンは、ブルテューの言う「階級のハビトゥス」は経済的基礎、とりわけ収入に 拘束されているが故に歴史的な説明を不可能にしている、と述べる [Gartman, 1991] 。 だが、ブルデューの理論（プラチック理論 ;une théorie de la pratique）には、 
その様な非醀は当たらない。何故なら、その理論に甚づいて為された研究の中には（ブル テュー自身の研究は勿論のこと、その協力者や弟子の研究も含めて）、階周関係の再生産 にのみ固執している訳ではないものも多いし、歴史的説明への糸口を与えているものもあ るからであり、また、本来、その理論に於いては、再生産の分析、構造的分析と、行為者 の実践の説明可能性とが結合しているからである。

本詥文では、先ず、階層関係の再生産を分析の主眼としている訳ではない研究成果を閱 しながら、行為者の実践と「場」や「資本」との関わりを考察する。それによって、ブル テューの理詥に対する非難の一つが解消するであろうからである。

続いて、その考察を踏まえた上で、ブルデューの理論へのもう一つの非難、即ち、「非 歴史的分析である」という偏見を、取り除く。この様な非難が為される背景には、「再生 産」という言莱を単なる「コピー」と受け止めてしまうという見方、ハビトゥスを「標造 化された構造」としてのみ捉えてしまっているという見方、ハビトゥスを全く変容可能性 の無いものとする見方、があるだろう。そこで、「ハビトゥス」が非歴史的な研究を招来 する概念ではないこと、フルデューの定式化した実践産出のメカニスムが歴史的な変動を 説明し得るものであること、について論ずる。また、フルデューの理論に於いて、いかな る歴史的変動がどう説明されるのか、という点をも明らかにする。

\section{2.ニつの事例研究}

ここでは、実践と場との関わりを論じているものとして、共に未邦訳の文献、フルルテュ 一の “Homo Academicus” [Bourdieu, 1984.] と、P.シャンパーニュの「文化資本 と経清資産」[Champagne，1987]（2）とを取り上げる。何故この二つを取り上げるの かと言えば、第一に、両者とも、ハビトゥスに基つくく実践が场の内部の変容といかに関わ り合うのか、という点や、その际の資本の変程の過程に着目して、実践産出を分析して いるからである。また、特に後者を取り上げるのは、「プラチック理論」はブルテュー以 外の学者によっても多方面に互って展開されているのだ、という事実を踏まえているから でもある。加えて、第二に、両者とも、歴史的な変娌過程の分析を試みているからだ。

“Homo Academicus”では、大学の埸という、固有の詥理を持った埸に新興勢力が参 入し、それと旧勢力とが対立して、結果的に埸の論理が变容して行く過程か、、「文化資本

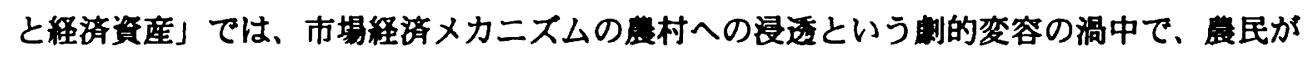
経営を自発的に維持・相繶する過程が（経斎的侧面には還元出来ない過程が）、分析され ている。

(1) 大学という「場」( "Homo Academicus" から)

フルテテーに扴れば、フランスの大学の墽は二つの敏対的なハイアラーキー化原理によ って組織されている、という[Bourdieu，1984 :70８8.] 。一方は、相続した資本と、 現に持つ経済的・政治的な資本とに照応した、社会的なハイアラーキーであり、他方は、 科学的権威や知的名声といった資本に照応した、特殊な文化的なハイアラーキーである。 両者の対立は、二つの竸合的な正統化原理の間の対立の場所である大学の埸の諸構造自体 
に固有のものなのだ。ここで、正統化原理とは、第一に、現世的・政治的なものであり、 そして、大学の場の論理の中に於いて、当の場か、梅力の場て効力を発揮する諸原理に寄 り掛かってい、ということを示してもいる。

例えば、右塄に投票したり、法律を教えたり、ローマ・カトリックであったりする大学 人と、左翼的見解を持っていたり、高等師筋学校を出ていたり、ユダヤ系であったりする それとが居る。前者の中には、様々な公職を果たしていたりはするものの、出版された本 が無いような者がある。また、彼らは大家族出身者であることが多かったり、裕福かつ実 力者であるという傾向が強い。一方、後者は、本を多数出版している者も多いが、資産の 点では前者と比べものにならない。ブルデューは、大学の場の成員の出身階層や家族構成、 宗教的背景、政治的見解と、彼らの研究領域とを関連させながら論を進めているのである。 即ち、それらの諸要来が相俟って、大学の埸の対立が形作られている訳だ。この场の中に 在る成員は、各々の意志に従って進路を選択しているのだが、実は、その選択は、上記の 諸要素の身体化の産物、ハビトゥスの産物なのである。この点に於けるブルデューの分析 には、礁かに、階首関係の再生産の強調が見られる。

前段落の記述からも判ることだが、ブルデューは、支配階級の中に在りかつ支配階級に 支眍されたものとして大学人を捉えてはいるものの、大学の教員の集団を一つの集団とし て扱っているのではない。前記の如く、或る教員の政治的見解一つを取ってみても、大学 てのその人の位置のみならず、その出身階層や専攻科目迄をも考虑に入れなければ判然と しない。だから、大学の教員の集団を単一で一枚岩的な秩序を持ったものと捉えることは、 不可能である。ブルデュー自身は次の様に述べる。

教授達の集団によって組織された一種の集団的防衛の様に思われるかも知れないもの は、何千もの、独立してはいるが調合された再生産戦略の諸結果や、その集団の保葠に 効果的に奇与する何千もの湖きかけの諸結果の集積でしかない。何故なら、それら諸結 果は、支配者のハビトゥスである社会的な保存本能の様なものの産物だからである。

[Bourdieu, 1984 :196]

そして、「再生産戦略」は、大学の埸の論理によって為されるのだ。ブルデューは、「場」 が、例えば大学の場の諞理が、相対的に自律的であることを指摘すると同時に、或る専攻 科目の埸が他のそれに影害を及ほすということを述べてもいる。「資本の種類と権力の形 態」(Espèces de capital et formes de pouvoir) と題された章の内、「共犯とし ての制対者」(Des adversaires complices) という節以降がその典型である [Bourdieu, $1984: 149 \sim 170$.$] 。$

ここで例示されているのは、R.バルトとR.ピカールとの間の対立だ。ピカールは文学研 究に専心する教授資格者であり、バルトは教授資格者ではなく、かつ、文学以外の言語学 や精神分析学、社会科学等を摄取した研究者であった。つまり、彼らは、互いに属する場 が違うのであり、対立の原因もそこに在るのだ。言い换えれば、或る埥の中には更に複数 の場があり得るのであり、彼らの対立とは、各々の场の論理によって与えられた役割を各々 が果たした結果に過ぎない。

1960 年頃迄のフランスの大学の場に於いては、教授を目指す学生の採るべきコースは決 
まっていた。即ち、教授資格試䀫に合格し、次いで博士号を取り、最終的には教授資格試 倹の審查員になる、というものであった。「最終的には教授資格試绘の審查員になる」と いうことは、救授達は自らの経て来たコース（大学の制度）を再生産するべく努めるとい うことを意味する。しかし、1960年代に入って、言語学や人類学等の科目が新たに影得力 を增すにつれ、事態は変わって行く。というのも、伝統的な教員採用の仕方では考えられ なかった科目を専攻した者が大学の埸に参入することにより、伝統的に正統と見做されて 来た科目の正統性が摇らいで来たからである。例えば、1960年頃迄は、伝統的に、大学の 文学の教授になりたい者は、教投資格試験を通り、文学だけに（例えば伝統的なラシーヌ 研究だけに）専心していれば良かったし、それで教授のポストへの道も開けた。ところが、 1960 年代に入ると、文学の教授資格を持たず、文学以外の科目を応用して文学研究をする 様な新参者が教授になり得る事態が生じた。結果的には、新参者の大学人の增加に、伝統 的な大学人が危機感を抱いた佮好である。前のバルトとピカールとの対立も、こうした事 情と同じ根を持つ。大学の場には固有の論理があった訳だが、様々な背景を持った勢力が 告めき合う事態が生じた結果、正統性を巡っての閍争が勃発したのである。

上述の様に、大学の埸に固有の論理は变容し得るものではあるが、但し、その論理は急 激に消隇するものではない。例えば、大学の埸で新参者のポストが確保されず、新参者が 助手等のポストにしか留まれない様な状況があったからこそ、1968 年 5 月の出来事が出 来したのだ、とブルテューは分析する。つまり、大学の堨の論理は、碓かに変容しつつあ つたのだが、その変容の渦中に於いては、依然として従来通りの論理が効力を持っていた のであり、それ故、新参者の不满が管積したのである。垻の論理は、従前の姿を留めつつ も少しずつ変容して行く訳であり、場に固有の論理が変容するということは、大変な時間 と困難とを伴うものなのだ。

（2）農民の家督相続と経営維持（「文化資本と経済資産」から）

シャンパーニュは、ブレス地方の農業という単一の場に於ける、家媤相䌇と経営䧴持の 実践を分析する。

1960 年代、農民の野望とは、継ぐべき家族経営さえ有ればそれを継ぐことなのであった。 しかし、1980 年代の後半には事情も変わり、大部分の農家では相繶者が居らず、かつ相䌇 を望みもしない。その様な変化の渦中で敢えて家督相絸する人の実践は、分析に值するだ ろう。

シャンパーニュは、農業の場の「社会空間」を、4 つの集団から成るものと見る。それ は、第一の次元として、経営规模で分けられ、10ヘクタール以下の最小経営農家（これを 仮に集団 $\mathrm{A}$ と呼ぶことにする）、中の下の経営農家（集団 B）、中の上の経営農家（集団 C）、50ヘクタール以上の最大経営農家（集団 D）である。勿論、経営は、Aから D へ移 るにつれて楽になる。この分類に、第二の次元として、学校的・文化的な次元を加味する と、それらの集団の社会的諸特性が現れる。集団 $A$ は、相綍人も無く、設備等の近代化に も無関心で、近くの都市で労㑬者や商人 (つまり非農民)になっている親族を多く持ち(と いうことは、地城的特性とは無縁だと言えるだろう）、教育等心（とは言っても、技術教 育の様な実用的なものであるが）である。集団 Bは、経済資本は中庸であって、親族の殆 
どが地域に根ざした弮民である様な人々の集団であり、学業や設備の近代化に無関心で、 技政的・経斎的変容を生き抜くのに棈一杯だ。集団 Cは、近代的且つ大規棋な経営で、経

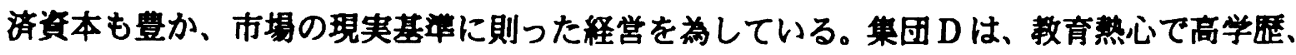
実践的カトリック信者、整った設供、全国紙の讜、という特性を持ち、地域的特性から

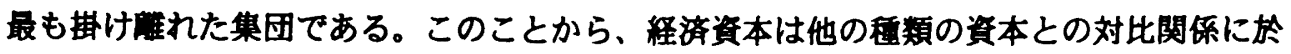
いてしか意味を成さない（経清資本の量だけで実践の方向性が決まる訳ではない）ことが 判る。そして、地域に残って家督を相続しようという者の多いのは、地域的特性の色渃い 集団 B ,Cだと言えるだろう。

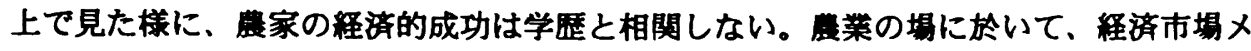
カニスムに適合するのに必要な文化資本の形愁は、「近代的」なものと思われ、「连和感 がある」と感じられる生活様式に対する、農民の通応力の中に見出されなければならない。 今や、地方の農村にも経济統合の波が押し奇せ、かつ、テレビ等の音及も慰民を国民的な 空間に統合するのに一役買っており、鹿村の脱地域化が進行している。そこで、シャンパ

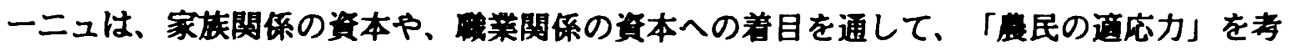
察する。

先ず、家族関保の資本（家族的な社会関係資本）を分析する為には、慰民が非晨業親族 をどれ程持つかという、家族成員の社会的分散を調べなければならない。家疾の各成員の 社会的軌道は、社会関俰資本の形愁を楎成する。だから、地域に根ざした経営を特性とす る集団 B，Cには家督相䌇人が多いし、地域的特性との緑が薄く学校教育を重視する集団 A,Dには相䌇人が少ないのである。

続いて、战業関係の資本であるか、、これは職業組織や組合主義と関保している。本来、 地域的な次元とは、地理的・道德的・社会的な秝序をイデロギー的に身体化するのに理 想的な社会集団を作るものであろう。だが、市䀘経済は、地域外的な論理に基づく経済の 過程を通用して、地域を徐々に变容させて行く。本節の冒頭にも述へた、1960年代には殆 どの鹿民が家㿟相䌇を望んだのに 1980 年代後半になるとそうではなくなる、という現象 も、市䀘経清メカニスムの浸透によって惹起された変容と見做し得る。その様な変容過程 の中て、、農民は、経営資本を增大させ設㑲投資する為に組合を作り、銀行に依存する様に なるのである。変容に適庞するには会計事務や技術革新等の必要が絶えず生じるので、農 民は最早、市埸経済化から逃れられない。こうして、市埸経济化に適応し得る莀民は新た な社会関保資本を形成しながらそれに適応し、適応し得ない農民はかつかつな生活を䌇け ることになる。

地域的な農業の場に於ける農民の実践は、経済資本とそれ以外の文化資本や社会関係資 本との相関によって定まるのであり、シャンパーニュは次の様に述べる。

例えば、経営の経济的側面と経営者の子供の学業との間に見られる関係は、学校の就業 過程が親の経消資本に直接的に左右されるということを意味している訳ではない。学業 の成功は家族（広い意味で親族も含んだ）の文化資本と結び付いているのだ。（中略） 絓営を経清的に発展させる为のものも、経済的次元の中に自らを変势するのも、共に文 化資本なのである。（中略）社会学者が経済資本と呼ぶものは、経㰷資産と、文化資本 やそれを持つものの関俰の資本との、独特の結合の産物なのである。[Champagne， 
前章で見た様に、埸の中に在る行為者は、「社会的世界がその当事者に客䀠的に与える チャンスの一定の状䈍」に対して、自らのハビトゥスに基づいて夷践を為す。

前の “Homo Academicus” からの引用に於いては、場は䙡合的であること、行為者の 実践は行為者自身の屈する埸の詥理に左右されること、そして、行為者のハビトゥスは、 行為者の背景にある諸要来の混合によって「構造化される」こと、が述べられていた。し かし、同時に、社会的世界の側の変化によって场の論理も変わり得るということが指描さ れているのも忘れてはならないだろう。行為者の夷践は彼らのハビトゥスに基づいている から、彼らは社会的世界の㑡の変化が自らの場をも変容させつつあることに気付いた時、 その変化に逆らおうとする（バルトに対決を挑んだピカールの様に）。何故なら、ハビト ウスは「恒常性」と「自己防御」とを保とうとするからである [Bourdieu， $1980: 101$ 〜102. = 1989 :97] 。その結果として、埸の内部で正統性を巡っての閣争が始まる。 バルトとピカールとの対立に関しては、結果的に、バルトに軍配が上がりヒカールが敗北 したと言えるだろう（刎これは便宜的な言い方であって、大学の場からビカール派がー 㧹された訳ではない）。バルトは、社会的世界の側の変化が大学の場にもたらした変容に 正に適合し得るハビトゥスを身体化していたのだ。従って、このことから次の様な推論が 成り立つ。即ち、それ迄ピカール派であった大学人も、彼らの自明性の中に在った自らの ハビトゥスの意識化を否応なく迫られ、結果として彼らのハビトゥスは变容して行った

[Bourdieu, $1980 ：$ 92〜93.=1989 :88] 。ハビトゥスが変容する」としたら、 先ずこの様な场合が孝えられるだろう。

「文化資本と経済資産」に於いては、展業の埸で農民達が諸資本を如何に卒换するのか、 という点に目が向けられている。実は、この論文にハビトゥスという概念は登場しないの

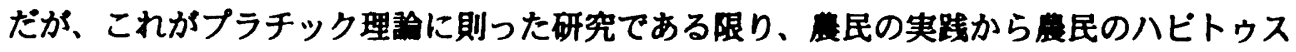
を捉えることが可能である。

先ず、集団 A,Dには相続人が少なく、集団 B,Cにはそれが多い、という事実は、相繶の 為され方が経济資本のみによって規定されている訳ではない点を行いたものである。攵家 の経営の相続は、鹿業の場の中の諸集団の各々が有する諸資本の結合の産物であるが、諸 筫本の結合の仕方は諸集団のハビトゥスに方向付けられているだろう。また、我々は、経 済市場メカニスムに対する展民の通応についてのシャンパーニュの分析を、「適応」とい う言莱に伴いがちな「受け身なもの」というイメージを払拭した上で読む必要がある。磪 かに、経倣市埸メカニズムの浸适は、経営を放棄する意志の無い昭民にとっては受容され るものでしかなかろう。だか、それは単なる受容ではない。行為者の実践は、一方的に「㮏 境」によって決定されるものではないのだ。行為者は、「環境」の変化の渦中に在って、 茫然自失しているのではない。彼らは、その時々に応じて、彼らが実践を為す陣に唯一扴 り所とし得るティィポジションたるハビトゥスに則って手持ちの諸資本を操る。結果とし て、農業の場に在っても、同様のハビトゥスを持つ者同士が自然に集まり、彼らは、組合 組織等を形成しつつ、即ち、伝統的な諸資本を新たな種類の社会関係資本に变換しつつ、 
実践を為したのであった。当然、旧態依然とした経営を行う者も居るし、新たな社会関俰 資本の形成に失敗した者もある筈だ。その様な仕漾に至ったのもまた、そういった人々の ハビトゥスに原因があるからだろう。

\section{4.社会空間としての堨に於けるハビトゥス}

バビトゥスが生み出す戦略は、「客睍的諸構造の産物であり、客覞的諸構造を再生産す る傾向を持つ」し、又、実践は、「過去にハビトゥスを作り出した諸条件に内在する规則 性を再生産する」 [Bourdieu，1980 ： 91〜103. =1989 : 86〜98] 。前に举げた 事例研究からも察しが付く通り、「再生産」とは、全くの同一物を生産し続けることなの ではない。未来に於いて行為者を熟うであろう出来事は予見不可能だか、出来事に対して、 行為者が自らのハビトゥスに則って実践を為すことは判っている。そして、実践の原理と なるティスポジションの權造であるハビトゥスが過去の産物である限りに於いて、実践の 多样性に限りがあるのは明らかであろう。行為者は、新たな出来事に対処した時、その出 来事への対処の仕方そのものを自らの過去として記篭する。そして、その対処の仕方もま た「過去にハビトゥスを作り出した諸条件に内在する規則性の再生産」に他ならない。言 い方を換えれば、それ迄に無かった出来事に対処しつつ行為者が実践を為すということは、 「過去にハビトゥスを作り出した諸条件」に新たな「条件」を付け加えてハビトゥスの「規 則性」を更新させることなのだ。実践はハビトゥスを原理としているのだから、ハビトゥ スを作り出した諸条件に内在する规則性を実践が再生産するのは当然であって、そのこと を、ハビトゥスはそれ自身の持つ规則性を維持する（「恒常性」、「自己防御」、先程の

“Homo Academicus” からの引用文では「社会的な保存本能」、等という記述はこの調 であろう）、と言い換えて良いだろゔ。ハビトゥスは、実践原理として実践の歴史的な首 尾一貫性（規則性）を保訨しつつ実践を産み出し、社会的世界から与えられる出来事に対 処して行為者が実践を為す度に更新されるのだから、非歴史的な研究を招来するどころか、 歴史的分析にはなくてはならぬものなのである。社会的な変勤も、ハビトゥスの現れと絡 めて説明され得る(3)。

例えば、“Homo Academicus” の列を実践産出のメカニスムに治って简略化するなら ぱ、次の様になるだろう。大学の埸にはバルトとビカールとに代表される二つの派䦥があ り、両者は各々固有の埸の論理に則って（各々のハビトゥスに則って）いた為に対立した。 それはまた、言語学等の新たな科目が影顠力を增した結果、従来大学の埸て支配的だった 側か、それまで被支配的であった新興勢力に正統性を車われるに至ったという、正統性を 巡っての街突なのであった。

一方、地方の鹿業の埸での、農家の家督相䌇及び経営維持の実践を分析したシャンパー ニュの論文を、同様に開略化してしまえば、以下の様になるだろう。地域的特性と密接に 結ひ付いた文化資本を有する集団の成貝は家督を相続する。そして、彼らは、地方への経 済市场メカニスムの浸逐という事態に直面した時、自らのハビトゥスに基づいて様々な社 会関俰資本を結合させ、新たな資本を形成しながら、今までとは異なった地域的農業経営 の在り方を創造した(4)。

罩竟、ハビトゥスとは、行為者の実践や行為の方向性を指し示すものであろう。独自の 
論理を持った場の中で、行為者は、ハビトゥスに方向付けられながら、実践し、行為する。 では、行為者がその中に位贯を占めている「場」とは、如何なる構造を持ったものなのだ ろうか。

社会的な場とは、「多次元的な位圈空間」である [Bourdieu, 1985 :724]。ここで、

「位圈」（positions）というのは、社会空間としての场の中で行為者が占める位置のこと を指している。そして、「社会空間」並びに「社会的な埸」は、次の二次元から成る。第 一の次元、即ち、諸行為者の持つ資本の総量と、第二の次元、即ち、彼らの資本の組み合 わせ（彼らの持つ全資本の中での、相異なる諸資本の比重。若しくは、彼らの持つ資本の 構造）。この二つの次元の交差によって、行為者の社会的な位贯は決まる [Bourdieu， 1985 :724] [Bourdieu, $1994: 20 \sim 22]$ (5)。

“Homo Academicus” からの例では、大学の埸の社会空間、前の要約简所で引用した 言莱を用いれば「二つの敏対的なハイアラーキー化原理」から成る场の社会空間も、相対 立する二つの集団の持つ資本の総量という次元と、その諸資本の比重という次元とによっ て、構成されている。即ち、右翼的意見、法律表攻、ローマ・カトリック、等といった特 徽と、左翼的意見、高等師螌学校出身、ユダヤ系、等といった特徽との対立を第一次元と し、文化資本よりも経済資本の方を多く持つという特鹳と、経済資本よりも文化資本の方 を多く持つという特徽との対立を第二次元とした社会空間が、大学の场の「ハイアラーキ 一化原理」を構成しているのた。。

また、「文化資本と経済資産」からの例では、経営規模の大小を第一次元とし、学校的・ 文化的な次元を第二次元とした社会空間を析出することによって、地方の晨業経営の維 持・相䌇が分析されている。

社会空間の中に位置付けられた行為者は、ハビトゥスに方向付けられ、自らの持つ諸資 本を基にして、社会的世界の中で、社会的世界の侧からの出来事にその都度僢時に対処し つつ、実践を産出するのである。

5.結語一ハビトゥスの变容可能性とプラチック理論の展開とを巡って一

行為者は「場」のどの位是に居るのか、ということを示すのが、「社会空間」としての 社会的な「場」なる概念扏組みである。そして、この概念枠組みこそが、ブルデューの理 論に於いて歴史分析はいかに為されるのか（歴史的な変较がどう分析されるのか）、とい う点を明らかにする鍵なのだ。即ち、“Homo Academicus”からの例で読み取れること だが、ブルデューは、まず分析対象たる場（大学の場）を措定し、その場の多次元的な社 会空間を析出する。続いて、その場がどのようにしてそのようなものになったのかという ことを、ブルデューは、社会的世界の側が場にもたらした影管（文学以外の学問領域の成 果を文学研究に適応した著者が評価されるといった現象）、それに伴う社会空間内での支

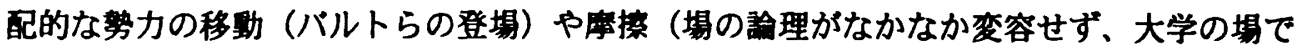
の新興勢力のポストが確保されないという状況が出来させた、1968 年 5 月の出来事）、 といつた現点から分析しているのである。

しかし、「社会空間」としての社会的な「場」という㯕念枠組みには、飽くまで、既察 者の視点から、言い換えれば、客涀主義的視点(6)から眺められたものだという澸みが残る。 
行為者は、実践に际して、埸に於ける自分の位贯を必ずしも意識している訳ではないのだ。 だから、「社会空間」と称するものの中に複数の次元を設定したり、それらの次元の中身 を特定することは、对象を現察し易くする為に睍祭者が行う作業に過ぎない。

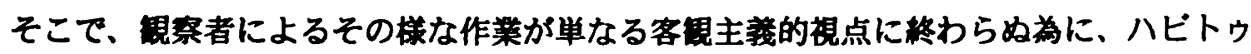
スという概念が必要になる。

ブルデューは、実践を、モデルとか役割の機能等に機械的に缱元出来るものではないと 孝えている。そして、実践の原理となる諸々のディスポジションのシステムたるハビトゥ スか、、規則への従属ではないが規則的な（régulier）もの」（ハビトゥスの定義から）

[Bourdieu, $1980: 88 \sim 89 .=1988$ :83〜84] である以上、ハビトゥスに基づいて為され る実践は、「無限で、相対的には予見不可能」である（状況が無限に在り得るから）もの の「多様性に於いては限界がある」(実践はハビトゥスによって限定されるから) [Bourdieu, $1980: 92 \sim 93 .=1988: 88]$ 。そして、ハビトゥスの現れとしての実践の内に、即ち、自 分では自分がハビトゥスに制限されているという実感が全く涌かないまま為される実践の 内に、ブルデューは行為者の能野性・自律性を見ている。つまり、ブルデューの理論に於 いて、行為者の能野性・自律性とは、その時々に応じてその都度瞬時にハビトゥスが行為 者の実践の中に現れる点に求められているのだ。

行為者は、自分の家族、自分の回りの人々、自分の育つ地域、自分の「聚境」といった、 個別性・具体性の中で成長する。そして、その成長の過程で、ハビトゥスを「実践的に修 得」(la maitrise pratique ; practical mastery) する(7)。

行為者はハビトゥスをいかにして㙏得するのだろうか。それを説明するに当たって、フ ルデューは、「内面化」という言萊を用いずに「身体化」（l'incorporation）という用語 を使用する。ハビトゥスは、人間が内面化する钼念のシステムなのではない。それは、フ ルデュー自身の用語を使えば、「身体的ヘクシス」（1'hexis corporelle）として「身体化」 された、諸々のティスポジションのシステムなのである。「振る舞う」とか「語る」とか、 或いはそれらを通して「感ずる」等といった実践、つまり、より身体に密着した実践を可 能にするハビトゥスを、ブルデューはヘクシスと呼んでいるものと考えられる [Bourdieu, 1980. :117〜119=1988:112〜115]。

だからこそ、幼児期や子供期には、ハビトゥスの変容が起こり易いだろう。実際、ブル デューもその点を指摘している [Bourdieu, 1977 :87] 。つまり、彼は、ハビトゥスを変 容させる契機として、子供の学校化（schooling）を挙げているのである。子供期に於け るハビトゥスの変容は、当事者たる子供にとっては全く意識化されずに為される埸合が多 いと言えるだろう。

一方、行為者がハビトゥスの変容を意識的に迫られる埸合もある。これは、“Homo Academicus”からの例で判るだろう。社会的世界の側の変化に伴って大学の場の論理が変 わりつつある時、それまでピカール派であった大学人も、彼らの自明性の中に在った自ら のハビトゥスの意識化を否応なく迫られ、結果として彼らのハビトゥスが変容する場合で ある。但し、「恒常性」、「自己防御」、「社会的な保存本能」等といったハビトゥスの 性格上、ピカール派大学人のハビトゥスが全く別のものになるということは孝えられない。 彼らのハビトゥスは、彼らが意識化し得た籍囲内で、元々のハビトゥスの許容樃囲内で、 変わるのである。 
「文化資本と経清資産」の例は、少し做妙である。鹿民は、市埸経済メカニスムのもた らした変化に道応しようとした。だが、道応し得た崖民は、受轩的に変化に棹さしたので はなかった。彼らは、ハビトゥスの方向付けに添い（彼らは、自分のハビトゥスを意識化 したのではなく、覀ろ譩化せぬままそれに則って変化に対処した）、諸資本を新たなも のに変换することを通じて、変化を乗り切ったのである。変化の後、彼らを取り巻く状況 が変わっている以上、彼らが今後体成する出来事も以前とは大いに異なったものになるだ ろう。結果的に、彼らのハビトゥスは、婳僅かずつではあれ、㚆化していく可能性がある。

フランスには、ウィットゲンシュタインの言う「規則」（[Wittgenstein, 1971. = 1978 :58] [Wittgenstein, 1953. =1976:160〜163])の方がブルデューの言う「ハ ビトゥス」よりも行為者をより自由なままにする、と主張する論者がいる [Chauviré, 1995 :552]。だが、私はその主張には異を唱えたい。ハビトゥスは、「規則」対「ハビ トゥス」として対立的に孝えられるべきものではない。ハビトゥスが変容不可能だと考え るから（礁かに、ハビトゥスは、その定義上、檑めて変容しにくいものであろう）、この 样な主張が出るのだ。「規則を知ること」が「ゲームをいかに綐けるかを知っていること」 であるならば、覀ろ、ハビトゥスとは、その䌇け方を行為者に指し示すディスポジション として、「規則」と「実践」とを媒介するものとして捉えられるべきである(8)。

最後に、フルルテューが自らの目指す理語の在り方を述べた一文を引用して楴め括りとし たい。

実践学 (praxéologie) は普過的な人類学であり、それは、諸行為者は普掘的に歴史的諸

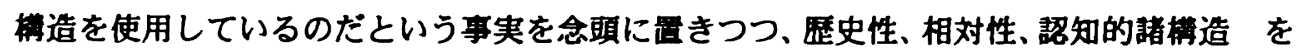
記録するものなのである。 [Bourdieu, 1994. :170〜171.]

《注》

(1) R.ハーカー他 [Harker, $1990=1993$ :296〜297.] の記述を引用しておく。「ブル テューが歴史的説明や歴史的な変容の説明を提供する気が無く、それ故転換の政治学を提 供する気も無い（そして、彼の同語反復的な手法の論理を通じて提供することは出来ない） という批判である。彼の最近の仕事の中では、（略）現在のフランスの知的な埸の起源の 説明を構成している。けれども、この再権成的な歴史はブルデューの著作の特徽ではない。

（中略）何故様々な埸が形成されるのかということに関する説明が不可避的に消失してい るからであり、それ故社会のトポロジーの説明が不十分だからである。」

(2) 私がこの論文 [Champagne,1987] の所在を知り興味を持ったのは、宮岛喬『文化的 再生産の社会学』 [宮岛, 1994] によるのであり、同書の特にIIー7 節から得る所が多か つた。

(3)この様な涀点は、例えば、ハビトゥスを「諸行為者を模格な决定論に閉じ込めること なく、諸実践に於いて相当な「プレイ」（jeu）を許容し、とりわけ即興を可能にする」も のと捉える論者達から見れば妥当な見解であろう。 [Chauviré, 1995 :552.]

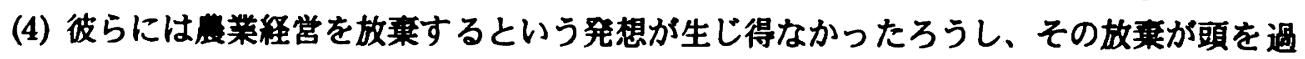


ぎったとしてもそれは克服すべき課題として捉えられたであろう。

(5) [Bourdieu, 1985 :724] 及ぴ [Bourdieu, 1994 :20〜22] が、「社会空間」に対し て分かり易い説明を与えている。だか、「社会空間」という概念を維横無尽に取使して成 果を挙げているのは、何と言っても「ティスタンクシオン] [ Bourdieu, 1979. =1990. ] である。

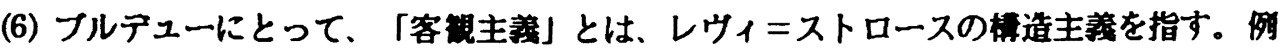
えは、レウィニストロースは、譄与交換の関係を空間の中に図式化した。その図式化では、 対抗贈与の為されるタイミングは全く無視されている。

レウィニストロースは、M.モ一スの論文集への序文 [Lévi-Strauss, C. 1968.=1973] の 中で、「梳合された全体は各棫部分よりも㬊かに全体的である」というモ一スの言菓を、 唱与交換の当事者速の主留（モ一スの言菓に従えは、「与える義移」、「受け取る義䅂」、 「返礼の義䅂」、等を證合させる一つのエネルギ一源としての、「ハウ」「マナ」等の観

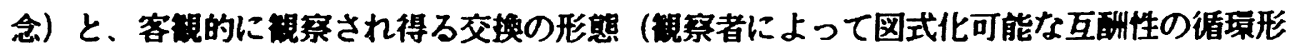
堵）とを切り唯すことなのたと曲解し、その故を以て、モ一スはモ一スの言菓に忠実でな いと批判している。モ一スが梳合された全体は各椿成部分よりも遥かに全体的である」

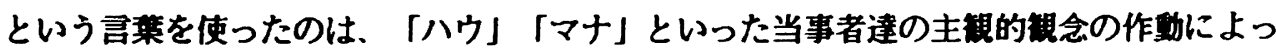
て交換は行われるのだ、という点を意識していたからなのに、である。レウィ＝ストロー

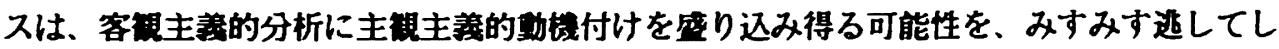
まったのだ。

贈与交换は、数学的樌造としてのみ表されるものなのではない。それは、時間(例えぱ、 対抗贈与の為されるタイミング)の既念、及び形式的モデルには僄元出来ないその悓念の変 異までをも加味して理論化されねばならない、というのがブルデューの主張である。対抗 贈与のタイミングは、その当事者たる行為者の胸先三寸に搔かっている。そのタイミング を見計らうということ（このこと自体、ハビトゥスの現れと言えるだろう）は、あらゆる 贈与交换につきものの戦略の一端なのである。だから、この埸合、時間の次元の中にこそ 行為者の「能隹性」が顥著に現れると言えるだろう [Bourdieu, $1980: 178 〜 183$ $=1988: 173 \sim 178]$ 。

(7)ここでは “la maitrise pratique”を「実践的修得」という風に訳しておいたが、これ は、「実践的珫制」とも訳し得る。因みに、[Bourdieu, 1970. =1991.]では、「実践的 支配」と訳されている。これは、身体化されたハビトゥスが実践に際して瞬時にその都度 現れ、その結果、実践が測則性を維持したものになるような様態を指している。“maitrise” という言莱には、修得したものに統制されている、という含意があると考えられる。

(8)ブウレス [Bouveresse, 1995 :573〜594]は、「規則」と「ハピトゥス」を対立 させることなく両者の間の差を掘り下げ、社会生活の中に両者が共存しているという事実 に目を向けるべきだと主張している。 


\section{《至考文嗝》}

Bourdieu, Pierre. 1970. Ia reproduction, Ed. de Minuit. = 1991. 宮島番郡「再生産」藤原書店

Bourdieu, Pierre. 1977. Outline of a Theory of Practice, Cambridge University Press.

Bourdieu, Pierre. 1979. Ia distinction, Ed. de Minuit. = 1990. 石井洋二郎郡「アィスタンクシオン」 1,2. 楌原店 Bourdieu, Pierre. 1980. Ie sens pratique, Ed. de Minuit. $=1988$ ( 1 巻);1990（2 巻） 今村他訳 「実践感覚』 みすず書层

Bourdieu, Pierre. 1984. Homo Academicus, Ed. de Minuit.

Bourdieu, Pierre. 1985. "The Social Space and the Genesis of Groups" , Theory and Society, vol. 14, no. 6.

Bourdieu, Pierre. 1994. RAISONS PRATIQUES, Sur la théorie de l'action. Le Sevil.

Bouveresse, Jacques. 1995. "Régles, dispositions et habitus" , Critique, no. 579-580, : 573 594.

Champagne, Patrick. 1987. "Capital culturel et patrimoine économique" , Actes de la Recherche en Sciences Sociales, no. 69. :51 66.

Chauviré, Christiane. 1995. "Des philosophes lisent Bourdieu" , Critique, no. 579-580, : :548 553.

Gartman, David. 1991. "Culture as Class Symbolization or Mass Reification? A Critique of Bourdieu's Distinction" , American Journal of Sociology, vol. 97 (2)

Harker, Richard. et. al. 1990. An Introduction to the Work of Plerre Bourdieu: The Practice of Theory, London: The Macmillan Press. $=$ 1993. 滝本他訳 「プルデュー入門一理論のプラチックー』 昭和堂

Lévi-Strauss, Claude. 1968. "Introduction aux écrits de Marcel Mauss", Mauss, Marcel. Sociologie et Anthropologie, 1968. P.U. F. $=1973$ 有地他訳「マルセル・モ一ス論文集への序文」。 M.モ一ス「社会学と人類学」-1，弘文堂.

宮岛 禹, 1994. 「文化的再生産の社会学』藤原書店.

Wittgenstein, I.udwig. 1971. Phllosophische Bemerkungen, Oxford: Basil Blackwell.

= 1978. 大森他訳 「ウィトゲンシュタイン全集』 -6 . 大修館書店.

Wittgenstein, Ludwig. 1953. Philosophische Untersuchungen,

Oxford: Basil Blackwell.

= 1976. 藤本隆志訳 「ウィトゲンシュタイン全集』 -8. 大修館费店. 